\title{
Program Bimbingan untuk Meningkatkan Kecakapan Self Direction Mahasiswa
}

\section{Rifda El Fiah}

\author{
Universitas Islam Negeri Raden Intan, Indonesia
}

Diterima: Juni 2017. Disetujui: Oktober 2017. Dipublikasikan: Desember 2017

\begin{abstract}
This research leads to the formation of self-guidance and academic guidance counseling program by academic advisors in assisting students to develop self-directed skills so that they can learn and lecture on campus effectively, so that universities can produce high achieving and qualified graduates as well always able to develop itself in accordance with the demands of the profession, the change of society, and the dynamics of life. This study uses descriptive approach, which aims to explain a situation in a systematic or explaining a particular field that became the center of the researcher's attention in factual and thorough, namely the dimensions of self-direction skills that should be owned by students in order to undergo the process of lectures and effective learning on campus UIN Raden Intan Lampung. The respondents involved 20 lecturers and 130 students. The results of this study indicate that more than 50\% of college students have low self-directed skills. Therefore, the lecturers are expected to have possess and master the guidance material, able to grow and develop students' self-confidence, able to communicate effectively and empathetically with the students, and always motivate the students, and develop positive, innovative and open attitude with the students.
\end{abstract}

Keywords: Guidance; Program; Student; Self; Direction

\begin{abstract}
Abstrak: Penelitian ini bermuara pada terbentuk program bimbingan kecakapan pengarahan diri dan strategi bimbingan akademik yang dilakukan dosen penasehat akademik dalam membantu mahasiswa mengembangkan kecakapan pengarahan diri agar nantinya mereka dapat melakukan pembelajaran dan perkuliahan di kampus secara efektif, sehingga perguruan tinggi dapat menghasilkan lulusan yang berprestasi dan bermutu serta senantiasa dapat mengembangkan dirinya sesuai dengan tuntutan profesi, perubahan masyarakat, dan dinamika kehidupan. Penelitian ini menggunakan pendekatan deskriptif, yang bertujuan untuk menjelaskan suatu situasi secara sistematik atau menjelaskan bidang tertentu yang menjadi pusat perhatian peneliti secara faktual dan teliti, yaitu dimensi-dimensi kecakapan pengarahan diri yang perlu dimiliki mahasiswa agar dapat menjalani proses perkuliahan dan pembelajaran yang efektif di kampus UIN Raden Intan Lampung. Responden penelitian melibatkan 20 orang dosen dan 130 orang mahasiswa. Hasil penelitian ini menunjukkan bahwa lebih dari $50 \%$ mahasiswa masik memiliki kecakapan pengarahan diri yang rendah. Oleh sebab itu, dosen diharapkan memiliki memiliki dan menguasai materi bimbingan, mampu menumbuhkan dan mengembangkan rasa percaya diri mahasiswa, mampu melakukan komunikasi yang efektif dan penuh empati dengan mahasiswa, serta selalu memotivasi mahasiswa, dan mengembangkan sikap positif, inovatif dan terbuka dengan mahasiswa.
\end{abstract}

Kata Kunci : Program; Bimbingan; Kecakapan; Self; Direction

\section{Pendahuluan}

Menghadapi proses pembelajaran di perguruan tinggi, mahasiswa dituntut untuk memiliki kepribadian yang efektif, kreatif, produktif dan mampu berinteraksi, menyesuaikan diri, mengelola, dan mendayagunakan lingkungannya sebagai fasilitas perkembangan yang kondusif. Untuk itulah mahasiswa seharusnya memiliki kemandirian dan tanggung jawab dalam mengembangkan inisiatif dan kemampuan memilih tindakan yang efektif dalam mencapai tujuan. Dewasa ini kemandirian dan tanggung jawab dalam menentukan pilihan dirasakan semakin penting untuk menghadapi kondisi kehidupan yang senantiasa bertambah kompleks. Dalam berbagai dimensi, kompleksitas tersebut menjadi bagian yang tidak terpisahkan dari setiap proses kehidupan. Selain itu perubahan dalam kehidupan yang semakin cepat dan meluas, 
menuntut individu untuk terlibat dalam proses belajar, penyesuaian diri, dan pengarahan diri (self direction) yang berlangsung sepanjang hayat(Suherman, Ilfiandra, \& NA, 2014).

Mahasiswa yang memiliki self direction yang baik tentunya secara simultan akan memiliki kemampuan mengarahkan hidupnya, dan tanggung jawab yang penuh terhadap konsekuensi dari perbuatannya. Dengan kata lain bila mahasiswa memiliki pengarahan diri maka jalan kehidupannya akan berjalan secara alamiah dan mampu mengembangkan perilakunya yang konsisten. Dalam Islam individu yang memiliki self direction yang baik berarti memiliki keistiqomahan (kemauan yang kuat untuk tidak menceburkan diri ke dalam perbuatan buruk). Individu yang demikian memiliki keteguhan hati, tidak mudah tergoda, senantiasa sabar, tidak melampaui batas. Namun orang yang tidak memiliki self direction yang baik cenderung lupa diri bahkan mudah putus asa.. Sebagaimana Firman Allah dalam AL Quran Surat Hud: 11 dan Surat Fushshilat 51:

"Maka tetapkanlah pendirianmu sebagaimana engkau disuruh, dan disuruhnya orang-orang yang bertaubat, serta janganlah melampaui batas. Sesungguhnya Dia maha melihat apa yang kamu kerjakan" (QS Hud: 11).

"Dan apabila kami memberikan nikmat kepada manusia ia berpaling dan menjauhkan diri; tetapi bila ia ditimpa malapetak maka ia banyak berdoa" (QS Fushshilat: 51)

Menurut Syamsu Yusuf terdapat tiga perilaku penting yang terkait dengan self direction, yakni self confidance, self reliance, dan self control.

Sejatinya mahasiswa yang sedang menjalani perkuliahan dan pembelajaran di perguruan tinggi memiliki tugas-tugas perkembangan yang harus dicapai dan senantiasa dituntut untuk (a) memiliki kemampuan mengembangkan diri secara optimal dengan memanfaatkan kelebihan diri serta memperbaiki kekurangan, (b) menunjukkan sikap percaya diri dan bertanggung jawab atas perilaku dan tindakannya, (c) memiliki kemampuan berpikir logis, kritis, kreatif, dan inovatif dalam mengambil keputusan, (d) menunjukkan sikap kompetitif dan sportif untuk mendapatkan hasil yang terbaik, (e) memiliki kemampuan menganalisis dan memecahkan masalah yang kompleks, (f) menghasilkan karya kreatif, baik individual maupun kelompok, dan (g) menguasai pengetahuan dan keterampilan yang diperlukan untuk melaksanakan proses belajar efektif. Dengan demikian mahasiswa yang memiliki kecakapan dalam pengarahan diri, akan memiliki kepekaan dalam melihat peluang, kekuatan untuk menghindari hambatan, kejelian dalam menghadapi tantangan, dan ketepatan dan konsistensi dalam melakukan tindakan. Jadi dalam melakukan aktivitasnya, mahasiswa akan memiliki selektivitas dan motivasi yang tumbuh dari dalam dirinya. Dengan demikian, pengarahan diri akan menjadi fasilitas dalam melakukan proses belajar efektif dan mencapai perkembangan yang optimal(Suherman et al., 2014).

Mahasiswa dalam kondisi dan dinamika demikian memerlukan uluran bantuan berupa layanan bimbingan dan konseling yang memfokuskan kepedulian kepada pengembangan pribadi, sosial, kematangan berpikir, dan sistem nilai serta kemampuan dan kecakapan pengarahan diri guna mengantisipasi dan mengambil keputusan secara efektif dalam menghadapi kehidupan di masa depan. Layanan yang dimaksud untuk mengembangkan kemampuan-kemampuan di atas adalah bimbingan dan konseling, namun dalam kenyatannya mahasiswa Jurusan Bimbingan dan Konseling semester dua dan enam Fakultas Tarbiyah dan Keguruan Univeritas Islam Negeri (UIN) Lampung belum memiliki kecakapan yang memadai dalam mengarahkan diri. Acapkali mahasiswa dalam menjalani kehidupannya di kampus terlihat gamang dalam menghadapi perubahan, keragaman pilihan, maupun persaingan. Sehingga tidak jarang ditemui mahasiswa 
merasa kebingungan, kebimbangan dan ketidakmatangan. Padahal sesungguhnya proses pembelajaran dan perkuliahan di perguruan tinggi ditujukan untuk menciptakan kondisi agar mahasiswa mampu membimbing, mengatur, dan mengarahkan dirinya dalam mencapai tujuan. Tidak jarang ditemui mahasiswa yang tidak memiliki keyakinan pada diri sendiri, seperti kemampuan mahasiswa untuk memasuki hubungan yang lebih intim dalam hubungan interpersonal. Dalam beberapa kasus biasanya mahasiswa mengalami frustrasi karena acapkali mengetahui apa yang mereka inginkan namun memiliki kekurangan kepercayaan diri untuk mengejar atau mempergunakan kemampuannya. Mereka membuat kesal dirinya sendiri karena menjadi tidak mampu dalam memenuhi kebutuhannya. Masalah interpersonal tampak saat mahasiswa merasa sulit untuk mencintai dengan sepenuhnya karena cinta mereka bersifat kondisional dengan indikator penggunaan prinsip, "Saya akan memberikan sesuatu pada kamu selama kamu memberikan sesuatu pada saya"(Yusuf, 2016).

Peserta didik masih kurang dalam aspek pengarahan diri dan penghargaan diri, sehingga diharapkan guru dan pihak sekolah dapat memberikan perhatian kepada para peserta didiknya untuk meningkatkan pengarahan diri dan penghargaan dirinya. Pengembangkan penelitian dengan tema yang sama, namun pada populasi dan sampel yang berbeda, di antaranya pada peserta didik SD, MTs, SMP, SMA, MA dan Perguruan Tinggi, sehingga dapat menghasilkan profil kompetensi intrapersonal pada jenjang yang lebih luas. Peneliti selanjutnya dapat menggunakan desain penelitian yang lain untuk mengetahui kompetensi intrapersonal peserta didik dan dapat menguji dengan menambah variabel lain selain kompetensi intrapersonal sehingga penelitiannya lebih kompleks dan komprehensif(Yulianty S, 2015).

Mahasiswa dalam kondisi dan dinamika demikian memerlukan uluran bantuan berupa layanan bimbingan yang memfokuskan kepedulian kepada pengembangan pribadi, sosial, kematangan karier dan sistem nilai serta kemampuan mengantisipasi dan mengambil keputusan secara efektif dalam menghadapi kehidupan di masa depan. Dengan kata lain perguruan tinggi dituntut untuk menyediakan program untuk mengembangkan kecakapan pengarahan diri pada mahasiswa. Sehingga dengan adanya program tersebut diharapkan mahasiswa akan memiliki kecakapan pengarahan diri, mampu menjalani kehidupannya secara terfokus, bertujuan, fungsional, dan dapat mengembangkan perkembangannya secara efektif dan efisien. Sehingga akhirnya mahasiswa memiliki kemampuan memilih berbagai alternatif dan mengambil keputusan serta secara positif merespon berbagai tantangan dan peluang yang terdapat pada diri dan lingkungannya. Dari hasil wawancara dan observasi yang dilakukan peneliti kepada mahasiswa semester dua dan enam Jurusan Bimbingan dan Konseling UIN Raden Intan Lampung menunjukkan tentang rendahnya kecakapan pengarahan diri yang dimiliki mahasiswa. Hasil wawancara dan observasi pada bulan November 2016 terhadap 80 orang mahasiswa Jurusan Bimbingan dan Konseling FTK UIN Lampung pada semester kedua angkatan 2016 menunjukkan $65 \%$ memilih jurusan di perguruan tinggi berdasarkan pengaruh guru, teman, dan orang tua; 55\% memiliki kebiasaan belajar yang kurang baik karena tidak mampu mengelola waktu, dan $40 \%$ tanpa perencanaan dan tujuan yang jelas mengikuti kegiatan ektrakurikuler, serta 35\% mengaku kurang memiliki kemampuan untuk mengambil keputusan (poor decision making).

Sebagai calon guru bimbingan dan konseling mahasiswa pada jurusan bimbingan dan konseling dituntut secara khusus untuk memiliki kualitas pribadi (kepribadian) konselor, yang menurut Michael E Cavanagh kepribadian konselor yang efektif adalah yang memiliki kualitas pribadi antara lain (1) self knowledge (pemahaman diri); (2) competence (kompetensi); (3) good 
psychological healt (kesehatan psikologis yang baik); (4) trustworthness (layak dipercaya); (5) honesty (kejujuran); (6) strength (kekuatan); (7) warmth (kehangatan); (8) active responsiveness (merespon aktif); (9) patiency (kesabaran); (10) sensitivity (kepekaan); (11) freeing (membebaskan); dan (12) holistic awareness (kesadaran holistik).

Sebagai profesi helper, konselor tidak harus menjadi model sehat psikologis yang ideal, namun harus memiliki kesehatan psikologis yang baik, sehat secara psikologis lebih sehat dari konselinya. Sebab ia ingin memiliki sifat-sifat yang ingin dikembangkan konseli melalui konseling. Indikator konselor yang memiliki kesehatan psikologis yang baik adalah ia mendapatkan kebutuhan seperti rasa aman, kasih sayang, bimbingan, kekuatan, dan afirmasi dari hubungan di luar hubungan konseling. Ia juga mampu memisahkan masalah masa lalu dan masalah pribadi saat ini di luar hubungan konseling. Memahami bias pribadi dan titik kelemahannya dan tidak hanya mampu bertahan hidup namun dapat menjalani hidup dengan baik. Tentu saja ia juga layak dipercaya karena ia bukan ancaman atau penyebab kecemasan bagi konselinya karena ia sebagai pendorong konselinya agar terbuka untuk memceritakan semua masalahnya. Tanpa kepercayaan maka konseling akan berakhir dengan frustrasi. Dengan rasa percaya maka konselor dapat diandalkan dan konsisten, meyakinkan baik verbal maupun nonverbal (bahwa kerahasiaan konseli adalah sesuatu yang mutlak), dan tentu saja tidak pernah membuat konseli menyesal telah membuka dirinya karena ia beertanggung jawab dalam arti sebenarnya.

Secara tegas dapat dikatakan bahwa pendekatan holistik dalam konseling mempunyai makna bahwa konselor menyadari keseluruhan individu (konseli) dan tidak melakukan pendekatan hanya dari satu aspek tertentu saja. Pendekatan holistik dalam konseling berarti bahwa konselor memahami konseli secara utuh dan tidak mendekatinya secara serpihan. Namun begitu bukan berarti bahwa konselor sebagai seorang ahli dalam segala hal. Konselor tidak boleh memiliki perasaan complitism. Di sini menunjukkan bahwa konselor perlu memahami adanya berbagai dimensi yang menimbulkan masalah konseli, dan memahami bagaimana dimensi yang satu memberi pengaruh dimensi yang lainnya. Dimensi-dimensi itu meliputi: fisik, intelektual, emosi, sosial, seksual, dan moral-spiritual(El Fiah, 2015).

Mengingat keseluruhan spektrum kualitas kepribadian konselor atau guru BK di atas adalah kemampuan yang diperlukan sebagai pijakan akademik yang kokoh dalam memberikan bantuan secara profesional maka dirasakan sangat perlu untuk mengembangkan kecakapan pengarahan diri kepada mahasiswa jurusan bimbingan dan konseling sebagai penopang kualitas pribadi konselor nantinya. Program dimaksud juga perlu diselenggarakan sebagai upaya untuk mengembangkan proses belajar efektif mahasiswa, sehingga mereka mampu menghadapi serangkaian tantangan dan mampu memanfaatkan setiap peluang dan fasilitas yang tersedia dalam mengoptimalkan perkembangannya. Dengan demikian mahasiswa diharapkan mampu menjalani proses perkuliahan dan pembelajaran secara lebih efektif, kreatif, dan produktif. Knowles mengemukakan bahwa pengarahan diri (self direction) merupakan pemusatan kekuatan psikologis dengan mengkonsentrasikan potensi-potensi yang dimiliki individu dalam proses meraih tujuan-tujuan hidupnya. Pengarahan diri mendorong individu untuk memiliki kepekaan, inisiatif, dan responsivitas dalam melihat dan memanfaatkan peluang-peluang yang tersedia, serta memiliki kemandirian dan tanggung jawab dalam menetapkan serangkaian pilihan tindakan guna memfasilitasi pencapaian tujuan yang ingin diraihnya. Kecakapan pengarahan diri perlu dikembangkan untuk membantu mahasiswa dalam mengantisipasi peranannya dalam kehidupan di masa akan datang. Pengarahan berkenaan dengan upaya mengoptimalkan pemanfaatan 
sumber-sumber dan fasilitas yang terdapat dalam diri dan lingkungan agar berkontribusi secara maksimal bagi pencapaian dan aktualisasi perkembangan optimal(Suherman et al., 2014).

\section{Metode Penelitian}

Sesuai dengan fokus dan pertanyaan penelitian serta tujuan penelitian maka penelitian ini menggunakan pendekatan deskriptif, yang bertujuan untuk menjelaskan suatu situasi secara sistematik atau menjelaskan bidang tertentu yang menjadi pusat perhatian peneliti secara fantual dan teliti(Arikunto, 2006). Dengan demikian penelitian ini dilakukan dalam rangka mendeskripsikan kondisi obyektif tentang dimensi-dimensi kecakapan pengarahan diri yang perlu dimiliki mahasiswa agar dapat menjalani proses perkuliahan dan pembelajaran yang efektif di kampus UIN Raden Intan Lampung; (1) pencapaian kecakapan pengarahan diri mahasiswa Jurusan Bimbingan dan Konseling UIN Raden Intan Lampung; (2) kompetensi-kompetensi yang perlu dimiliki oleh dosen PA dalam mengembangkan kecakapan pengarahan diri mahasiswa agar dapat menjalani proses perkuliahan dan pembelajaran secara efektif yang nantinya dijadikan sebagai salah satu dasar penyusunan program layanan bimbingan pengembangan kecakapan pengarahan diri mahasiswa Jurusan Bimbingan dan Konseling UIN Raden Intan Lampung(El Fiah \& Rinaldy, 2015).

Responden yang terlibat dalam penelitian ini terdiri dari (1) unsur pimpinan, yaitu rektor dan dekan Fakuktas tarbiyah dan Keguruan, (2) dosen PA, dan (3) mahasiswa. Dari pihak dosen ditetapkan sebanyak 20 responden yang dianggap mengetahui atau diperkirakan dapat memberikan masukan serta tanggapan terhadap upaya pengembangan program layanan bimbingan pengembangan kecakapan pengarahan diri mahasiswa jurusan Bimbingan dan Konseling Fakultas Tarbiyah dan Keguruan UIN Raden Intan Lampung. Sedangkan dari pihak mahasiswa dilibatkan 160 mahasiswa (semester dua dan enam) dari keseluruhan mahasiswa Jurusan BK FTK UIN Raden Intan Lampung dan diminta mengisi angket alat pengungkap kecakapan pengarahan diri.

Untuk memperoleh data yang dibutuhkan guna tersusunnya Program Pengembangan Kecakapan Pengarahan Diri bagi Mahasiswa yang memiliki ketepatan, terpercaya, dan dapat digunakan dalam layanan bimbingan akademik, peneliti mengadopsi alat pengungkap data(Suherman et al., 2014). Alat ungkap ini dikembangkan dalam dua perangkat instrumen penelitian, yaitu: (1) Angket Pengungkap Kecakapan Pengarahan Diri Mahasiswa, digunakan untuk menjaring data kepemilikan kecakapan pengarahan diri mahasiswa, (2) Angket Pengungkapan Kompetensi Pembimbing Akademik dalam Proses Pengembangan Kecakapan Pengarahan Diri, sebagai alat pengungkap kompetensi Dosen Pembimbing Akademik yang diperlukan dalam bimbingan akademik guna memfasilitasi mahasiswa mengembangkan kecakapan pengarahan diri.

Penelitian ini akan menghasilkan dua kelompok data, yaitu pertama data tentang kepemilikan kecakapan pengarahan diri mahasiswa dan kedua, data kompetensi Dosen Pembimbing Akademik yang diperlukan dalam bimbingan akademik guna memfasilitasi mahasiswa mengembangkan kecakapan pengarahan diri. Kedua data dimaksud adalah data kuantitatif, yaitu berupa kecenderungan responden terhadap setiap item pernyataan dalam instrumen. Selanjutnya kedua data tersebut dianalisis dengan menggunakan analisis statistik deskriptik yang dibantu dengan bantuan perangkat lunak program SPSS.

\section{Hasil dan Pembahasan}


Identifikasi tentang pencapaian kecakapan pengarahan diri mahasiswa Jurusan Bimbingan dan Konseling UIN Raden Intan Lampung dilakukan melalui analisis pemilikan kecakapan pengarahan diri mahasiswa, dengan melaksanakan survey terhadap 160 mahasiswa dari keseluruhan mahasiswa Jurusan BK FTK UIN Raden Intan Lampung dan diminta mengisi angket alat pengungkap kecakapan pengarahan diri. Mahasiswa yang menjadi responden dalam penelitian ini adalah mahasiswa semester dua (angkatan 2016-2017) dan mahasiswa semester enam (angkatan 2014-2015). Hasil identifikasi menunjukkan bahwa mahasiswa semester dua dan enam memiliki gambaran pengarahan diri yang rendah (table 1).

Tabel 1 Profil Kecakapan Pengarahan Diri Mahasiswa

\begin{tabular}{|c|c|c|c|}
\hline Kategori & Rentang Skor & F (Frekuensi) & $\%$ \\
\hline Sangat Tinggi & $13-15$ & 0 & 0 \\
\hline Tinggi & $10-12$ & 10 & 6,875 \\
\hline Sedang & $7-9$ & 74 & 46,25 \\
\hline Rendah & $4-6$ & 65 & 40,625 \\
\hline Sangat Rendah & $1-3$ & 11 & 6,875 \\
\hline & Total & 160 & 100 \\
\hline
\end{tabular}

Sebagai pendidik peran pembimbing akademik dalam upaya mengembangkan kecakapan pengarahan diri mahasiswa diwujudkan dengan cara mengupayakan dan memberikan sejumlah kesempatan selama dan sesudah bimbingan berupa keberanian mahasiswa untuk memilih dan membuat keputusan, bertanggung jawab atas keputusan yang diambilnya, dan mengatasi masalah yang dihadapinya.

Untuk mewujudkan hal-hal dimaksud maka terdapat beberapa tujuan yang ingin dicapai dengan melakukan bimbingan akademik, antara lain membantu mahasiswa untuk (a) memperoleh dan mengelola proses informasi secara efektif; (b) mengembangkan dan memiliki rasa percaya diri pada mahasiswa; (c) meyakinkan mahasiswa bahwa mereka memiliki potensi untuk meraih kesuksesan; dan (d) lebih reflektif dan berani dalam berpikir dan bertindak.

Dari pernyataan di atas maka dapat disimpulkan bahwa seorang dosen PA haruslah memiliki dan mengembangkan hal-hal berikut guna memfasilitasi pengembangan kecakapan pengarahan mahasiswa yang dibimbingnya.

a. Senantiasa memiliki dan menguasai materi bimbingan pengarahan diri yang melingkupi antara lain (1) membuat rencana materi bimbingan pengarahan diri; (2) menguasai materi bimbingan pengarahan diri; dan (3) menyajikan dan melaksanakan materi bimbingan pengarahan diri yang dimaksud.

b. Senantiasa menumbuhkan dan mengembangkan kepercayaan diri mahasiswa dengan cara antara lain (1) melakukan kerja sama; (20 bersikap sabar; dan (3) sensitif terhadap pikiran, perasaan, dan kesulitan mahasiswa.

c. Melakukan komunikasi yang empatik dan efektif dengan mahasiswa sebagai bentuk pengembangan kemampuan interpersonal dengan cara antara lain (1) menunjukkan perhatian yang hangat kepada seluruh mahasiswa; (2) bersahabat, hangat, dan ramah; (3) peka dan memahami ekspresi lisan, tulisan, dan perilaku mahasiswa (verbal dan nonverbal). 
d. Senantiasa memotivasi mahasiswa sehingga timbul dorongan dalam diri mahasiswa dengan cara (1) menerima dan mempercayai segala upaya mahasiswa; (2) tidak pernah mematikan upaya mahasiswa namun selalu menyemangati mahasiswa untuk mencoba dan melakukan hal-hal yang positif, dan (3) hendaklah memberikan penghargaan atas hasil yang diraih mahasiswa.

e. Senantiasa mengembangkan sikap positif, inovatif, dan terbuka, dengan melakukan halhal (1) bersikap terbuka terhadap ide, pendapat, dan saran dari mahasiswa; (2) ramah dan penuh pemahaman dan pengertian; (3) hangat, bergairah, dan menerima mahasiswa apa adanya; (4) memodifikasi atau mengganti pola-pola perilaku mahasiswa yang maladaptif (self destructive).

Di sinilah dosen PA sebagai orang yang seyogyanya berperan dalam pengarahan diri mahasiswa mulai memberikan dukungan yang cukup kepada mahasiswa bimbingannya. Agar dengan adanya dukungan ini mahasiswa merasa siap untuk mengambil resiko dalam kehidupannya (dalam perkuliahan maupun di luar kampus). Mahasiswa diharapkan untuk tidak selalu memanfaatkan dosen PA sebagai manajer yang akan selalu mendukung, namun dimaksudkan agar mahasiswa dapat menyadari tujuan bimbingan dari dosen PA yang sebenarnya dan mampu memandang secara akurat tentang peran dosen PA.

Dosen PA dapat menjelaskan kepada mahasiswa bimbingannya tentang perlunya membuat perencanaan dalam setiap kegiatan agar tidak menjadi sia-sia. Perencanaan yang baik membuat pekerjaan lebih terarah. Menurut Suherman dkk agar setiap kegiatan dan kehidupan mahasiswa lebih terarah dapat dimulai dengan mengenali diri sendiri. Mengenali diri dapat diawali dengan mengetahui tujuan hidup, mengenali tipe pribadidan membuat rencana kegiatan yang mengarah pada tujuan hidup. Baik rencana jangka panjang (tahinan) maupun rencana jangka pendek (bulanan, mingguan, dan harian). Kecakapan inisiatif ini dapat dikembangkan dengan cara (a) mengidenifikasi kegiatan yang utama; (b) membuat jadwal kegiatan yang diprioritaskan; dan (c) membuat jadwal untuk kegiatan lainnya. Jenis dan isi materi bimbingan kecakapan pengarahan diri yang diadopsi dari Herman dkk. dengan penyesuaian pada lokasi penelitian.

\begin{tabular}{|l|l|l|l|l|l|l|l|}
\hline No & $\begin{array}{l}\text { Aspek } \\
\text { Bim- } \\
\text { bingan }\end{array}$ & $\begin{array}{l}\text { Tujuan } \\
\text { Bimbingan }\end{array}$ & $\begin{array}{l}\text { Materi } \\
\text { Bimbing-an }\end{array}$ & $\begin{array}{l}\text { Prosedur } \\
\text { Bimbingan }\end{array}$ & $\begin{array}{l}\text { Metode \& } \\
\text { Seting } \\
\text { Bimbing-an }\end{array}$ & $\begin{array}{l}\text { Media } \\
\text { Bim- } \\
\text { bingan }\end{array}$ & $\begin{array}{l}\text { Wak-tu } \\
\text { Bim- } \\
\text { bing-an }\end{array}$ \\
\hline
\end{tabular}




\begin{tabular}{|c|c|c|c|c|c|c|c|}
\hline 1. & $\begin{array}{l}\text { Pengemb } \\
\text { angan } \\
\text { Kecakap } \\
\text { an } \\
\text { Inisiatif }\end{array}$ & $\begin{aligned} & \text { 1. } \begin{array}{l}\text { Mampu } \\
\text { membuat } \\
\text { perencanaan }\end{array} \\
& \text { yang baik. } \\
& \text { 2. } \begin{array}{l}\text { Mampu } \\
\text { mengidentif }\end{array} \\
& \text { ikasi } \\
& \text { kegiatan utk } \\
& \text { melaksanak } \\
& \text { an rencana } \\
& \text { Koopera-tif } \\
& \text { dalam } \\
& \text { mencapai } \\
& \text { rencana }\end{aligned}$ & $\begin{array}{l}\text { 1. Membu-at } \\
\text { rencana } \\
\text { 2. Me- } \\
\text { ngenda- } \\
\text { likan } \\
\text { kegiatan } \\
\text { 3. Menjalin } \\
\text { kerja sama }\end{array}$ & $\begin{array}{l}\text { 1.Pengondisi-an } \\
\text { Mahasiswa } \\
\text { 2. Dosen PA } \\
\text { memba-ngun } \\
\text { minat \& } \\
\text { komitmen } \\
\text { kerjasama } \\
\text { antar } \\
\text { kelompok } \\
\text { 3.Penyampaian } \\
\text { materi \& } \\
\text { brainstorm- } \\
\text { ming } \\
\text { 4. Mhs dan } \\
\text { DPA } \\
\text { mengada-kan } \\
\text { refleksi }\end{array}$ & $\begin{array}{l}\text { Bimbing-an } \\
\text { kelompok } \\
\text { atau klasikal } \\
\& \quad \text { ice } \\
\text { breaking, } \\
\text { pengajar-an, } \\
\text { brainstormm } \\
\text { ing, kuis, } \\
\text { simulasi } \\
\text { (indoor \& } \\
\text { outdoor) }\end{array}$ & $\begin{array}{l}\text { Bola, } \\
\text { kertas } \\
\text { kosong, } \\
\text { agenda } \\
\text { mandiri, } \\
\text { lembar } \\
\text { kerja } \\
\text { pengem- } \\
\text { bangan } \\
\text { rencana } \\
\text { hidup }\end{array}$ & $\begin{array}{l}120 \\
\text { menit } \\
\text { (utk } \\
\text { dua } \\
\text { kali } \\
\text { perte- } \\
\text { muan) }\end{array}$ \\
\hline 2. & $\begin{array}{l}\text { Pengem- } \\
\text { bangan } \\
\text { Keca- } \\
\text { kapan } \\
\text { Oto- } \\
\text { nomi }\end{array}$ & $\begin{array}{l}\text { 1.Mampu } \\
\text { merumus-kan } \\
\text { tujuan } \\
\text { 2.Mampu } \\
\text { merumus-kan } \\
\text { misi pribadi } \\
\text { 3. Mampu } \\
\text { memahami } \\
\text { kekuatan dan } \\
\text { kelemahan } \\
\text { diri }\end{array}$ & $\begin{array}{l}\text { 1.Mene- } \\
\text { tapkan } \\
\text { tujuan } \\
\text { 2.Meru- } \\
\text { muskan } \\
\text { misi } \\
\text { pribadi } \\
\text { 3. Mema- } \\
\text { hami } \\
\text { kekuatan } \\
\text { dan kele- } \\
\text { mahan diri }\end{array}$ & $\begin{array}{l}\text { 1.Pengondi-sian } \\
\text { mahasiswa } \\
\text { 2.Pretes untuk } \\
\text { mengukur } \\
\text { profil } \\
\text { kecakapan } \\
\text { otonomi mhs. } \\
\text { 3.Pemben-tukan } \\
\text { kelompok } \\
\text { 4.DPA dan mhs } \\
\text { membangun } \\
\text { minat dan } \\
\text { komitmen } \\
\text { kerja. } \\
\text { 5.Simulasi } \\
\text { menembak, } \\
\text { kuis, diskusi } \\
\text { \& refleksi. } \\
\text { 6.Penyampai-an } \\
\text { materi, tugas \& } \\
\text { brainstorm- } \\
\text { ming. } \\
\text { DPA \& mhs } \\
\text { mengadakan } \\
\text { refleksi }\end{array}$ & $\begin{array}{l}\text { Bimbingan } \\
\text { kelompok } \\
\text { atau klasikal } \\
\& \quad \text { ice } \\
\text { breaking, } \\
\text { pengajaran, } \\
\text { brainstorm- } \\
\text { ming, kuis, } \\
\text { simulasi. } \\
\text { (indoor \& } \\
\text { outdoor) }\end{array}$ & $\begin{array}{l}\text { Proyek- } \\
\text { tor, } \\
\text { kertas } \\
\text { kerja, } \\
\text { simula- } \\
\text { si, } \\
\text { lembar } \\
\text { kuis, } \\
\text { karton, } \\
\text { pistol } \\
\text { mainan. }\end{array}$ & $\begin{array}{l}120 \\
\text { menit } \\
\text { (utk } \\
\text { dua } \\
\text { kali } \\
\text { perte- } \\
\text { muan) }\end{array}$ \\
\hline
\end{tabular}




\begin{tabular}{|c|c|c|c|c|c|c|c|}
\hline 3. & $\begin{array}{l}\text { Pe- } \\
\text { ngem- } \\
\text { bangan } \\
\text { Kecakap } \\
\text { an } \\
\text { Fleksi- } \\
\text { bilitas }\end{array}$ & $\begin{array}{l}\text { 1.Mampu } \\
\text { menyesuai- } \\
\text { kan diri scr } \\
\text { positif dg } \\
\text { perubahan } \\
\text { yang terjadi } \\
\text { dalam } \\
\text { kehidupan } \\
\text { 2.Memiliki } \\
\text { kesadaran diri } \\
\text { \& mengguna- } \\
\text { kan hati } \\
\text { nurani dlm } \\
\text { menentu-kan } \\
\text { pilihan hidup } \\
\text { 3.Mampu } \\
\text { mengem- } \\
\text { bangan } \\
\text { imajinasi } \\
\text { positif }\end{array}$ & $\begin{array}{l}\text { Fleksibi-litas } \\
\text { merupa-kan } \\
\text { kemampu-an } \\
\text { dlm menye- } \\
\text { suaikan diri } \\
\text { mengha-dapi } \\
\text { segala } \\
\text { situasi }\end{array}$ & $\begin{array}{l}\text { 1.Pengondi-sian } \\
\text { mahasiswa } \\
\text { dan membuat } \\
\text { kelompok } \\
\text { 2.DPA memba- } \\
\text { ngun minat } \\
\text { dan komitmen } \\
\text { kerja sama } \\
\text { 3.Simulasi } \\
\text { dengan } \\
\text { "Pohon } \\
\text { Harapan". } \\
\text { 4.Simulasi ttg } \\
\text { optimis dan } \\
\text { pesimis, kuis, } \\
\text { diskusi \& } \\
\text { refleksi. } \\
\text { 5.Materi } \\
\text { "Penyesuaian } \\
\text { Diri } \\
\text { Positif", Scr } \\
\text { barins- } \\
\text { torming. } \\
\text { 6.Refleksi } \\
\text { seluruh } \\
\text { kegiatan }\end{array}$ & $\begin{array}{l}\text { Bimbing-an } \\
\text { kelom-pok } \\
\text { atau klasikal } \\
\text { \& ice } \\
\text { breaking, } \\
\text { pengajar-an, } \\
\text { brains- } \\
\text { torming, } \\
\text { kuis, } \\
\text { simulasi. } \\
\text { (indoor \& } \\
\text { outdoor }\end{array}$ & $\begin{array}{l}\text { Proyek- } \\
\text { tor, } \\
\text { kertas } \\
\text { kerja, } \\
\text { simula- } \\
\text { si, } \\
\text { lembar } \\
\text { kuis, } \\
\text { kertas } \\
\text { lipat, } \\
\text { gunting, } \\
\text { double } \\
\text { tip, } \\
\text { karton }\end{array}$ & $\begin{array}{l}120 \\
\text { menit } \\
\text { (utk } \\
\text { dua } \\
\text { kali } \\
\text { perte- } \\
\text { muan) }\end{array}$ \\
\hline 4 & $\begin{array}{l}\text { Pe- } \\
\text { ngem- } \\
\text { bangan } \\
\text { Keca- } \\
\text { kapan } \\
\text { Tang- } \\
\text { gung } \\
\text { Jawab }\end{array}$ & $\begin{array}{l}\text { 1.Mampu } \\
\text { mengambil } \\
\text { keputusan } \\
\text { dengan tepat } \\
\text { 2. Keberanian } \\
\text { mengambil } \\
\text { resiko } \\
\text { 3.Komitmen } \\
\text { yang tinggi } \\
\text { 4.Orientasi nilai } \\
\text { yang positif }\end{array}$ & $\begin{array}{l}\text { 1.Langkah } \\
\text { dan } \\
\text { strategi } \\
\text { pengam- } \\
\text { bilan } \\
\text { keputus-an } \\
\text { 2.Kebera- } \\
\text { nian } \\
\text { meng- } \\
\text { ambil } \\
\text { resiko } \\
\text { 3.Pening- } \\
\text { katan } \\
\text { komit-men } \\
\text { diri } \\
\text { 4.Orienta-si } \\
\text { nilai } \\
\text { dalam } \\
\text { kehidup- } \\
\text { an }\end{array}$ & $\begin{array}{l}\text { 1.Pengondi-sian } \\
\text { mahasiswa } \\
\text { 2.DPA memba- } \\
\text { ngun minat } \\
\text { dan komitmen } \\
\text { kerja sama } \\
\text { 3.Simulasi ttg } \\
\text { Keberanian } \\
\text { mengambil } \\
\text { resiko. } \\
\text { 5.Materi } \\
\text { "Gunakan } \\
\text { tindakan utk } \\
\text { hilangkan rasa } \\
\text { takut dan } \\
\text { capai } \\
\text { kepercaya-an } \\
\text { diri", barins- } \\
\text { torming. } \\
\text { 6.Refleksi } \\
\text { seluruh } \\
\text { kegiatan } \\
\end{array}$ & $\begin{array}{l}\text { Bimbing-an } \\
\text { kelompok } \\
\text { atau klasikal } \\
\& \quad \text { ice } \\
\text { breaking, } \\
\text { penga-jaran, } \\
\text { brains- } \\
\text { torming, } \\
\text { kuis, } \\
\text { simulasi. } \\
\text { (indoor \& } \\
\text { outdoor }\end{array}$ & $\begin{array}{l}\text { Proyek- } \\
\text { tor, } \\
\text { kertas } \\
\text { kerja, } \\
\text { simulasi, } \\
\text { lebar } \\
\text { kuis, } \\
\text { kertas } \\
\text { lipat, } \\
\text { gunting, } \\
\text { double } \\
\text { tip, } \\
\text { karton }\end{array}$ & $\begin{array}{l}120 \\
\text { menit } \\
\text { (utk } \\
\text { dua } \\
\text { kali } \\
\text { perte- } \\
\text { muan) }\end{array}$ \\
\hline
\end{tabular}

Simpulan dan Saran

Berdasarkan hasil penelitian dan pembahasan yang berhubungan dengan pengembangan program bimbingan kecakapan pengarahan diri bagi mahasiswa Prodi Bimbingan dan Konseling (BK) Fakultas Tarbiyah dan Keguruan (FTK) UIN Raden Intan Lampung maka dapat diambil suatu simpulan sebagai berikut. Pertama, berkenaan dengan pemotretan kondisi obyektif di 
lapangan menunjukkan bahwa mahasiswa Prodi Bimbingan dan Konseling Fakultas Tarbiyah dan Keguruan UIN Raden Intan Lampung sebagian besar menunjukkan kecakapan pengarahan diri rendah yang teridentifikasi dentifikasi mengenai pencapaian kecakapan pengarahan diri melalui analisis pemilikan kecakapan pengarahan diri mahasiswa. Hasil identifikasi menunjukkan bahwa mahasiswa semester dua dan enam memiliki gambaran pengarahan diri yang rendah. Kedua, dari pemotretan konddisi obyektif dilapangan maka kompetensikompetensi yang perlu dimiliki oleh dosen PA dalam mengembangkan kecakapan pengarahan diri mahasiswa agar dapat menjalani proses perkuliahan dan pembelajaran secara efektif adalah (a) senantiasa memiliki dan menguasai materi bimbingan pengarahan diri; (b) senantiasa menumbuhkan dan mengembangkan kepercayaan diri mahasiswa; (c) melakukan komunikasi yang empatik dan efektif dengan mahasiswa sebagai bentuk pengembangan kemampuan interpersonal; (d) senantiasa memotivasi mahasiswa sehingga timbul dorongan dalam diri mahasiswa; dan (e) senantiasa mengembangkan sikap positif, inovatif, dan terbuka.

\section{Daftar Pustaka}

Arikunto, S. (2006). Dasar-dasar Evaluasi Pendidikan. Jakarta: Bumi Aksara.

El Fiah, R. (2015). Dasar-dasar Bimbingan dan Konseling. Yogyakarta: Idea Press.

El Fiah, R., \& Rinaldy, R. (2015). Pengaruh Pendekatan Somatis, Audiotori, Visual Intelektual (SAVI) Berbasis Brain Gym Terhadap Hasil Belajar Kognitif Peserta Didik Pada Materi Pencemaran Lingkungan. Konseli, 2(1), 22-26.

Suherman, Ilfiandra, \& NA, S. (2014). Model Bimbingan Untuk Meningkatkan Kecakapan Pengarahan Diri.

Yulianty S, N. (2015). Efektivitas Bimbingan Pribadi-Sosial Untuk Mengembangkan Kompetensi Intrapersonal Peserta Didik. Jurnal Bimbingan Dan Konseling Islam, 5(1), 2644.

Yusuf, S. (2016). Konseling Individual Konsep Dasar \& Pendekatan. Bandung: Refika Aditama. 